\title{
EFFECTS OF WORK MOTIVATION AND ORGANIZATIONAL CULTURE ON EMPLOYEE PERFORMANCE AT DR. ACHMAD DIPONEGORO HOSPITAL
}

\author{
Atmiyati, Qurratul Aini \\ Masters Program in Hospital Management, Universitas Muhammadiyah Yogyakarta
}

\begin{abstract}
Background: Hospital has roles in developing and maintaining public health. In hospital service, employees contribute in the success of services. But there are still employees who lose motivation in work and environmental changes. Intense competition may inadvertently make the quality of service to decrease. This study aimed to examine the effects of work motivation and organizational culture on employee performance at Dr. Achmad Diponegoro Hospital.

Subjects and Method: This was a cross-sectional study conducted at Dr. Achmad Diponegoro Hospital, West Kalimantan. A total of 137 employees were selected in this study. The dependent variable was employee performance. The independent variables were work motivation and organizational culture. The data were collected using questionnaire, consisted of 12 motivational, 6 organizational culture, and 12 performance items. The data were analyzed using a multiple linear regression.

Results: Work motivation and organizational culture were positively associated with employee performance.

Conclusion: Work motivation and organizational culture are positively associated with employee performance.

Keywords: work motivation, organizational culture, employee performance

\section{Correspondence:}

Atmiyati. Masters Program in Hospital Management, Universitas Muhammadiyah Yogyakarta, D.I Yogyakarta, Indonesia. Email: berdoajanganlupa427@gmail.com. Mobile: o81257166680.
\end{abstract}

The $6^{\text {th }}$ International Conference on Public Health

Best Western Premier Hotel, Solo, Indonesia, October 23-24, 2019 | 284

https://doi.org/10.26911/the6thicph.04.46 